\title{
Prolonged AMPK activation increases the expression of fatty acid transporters in cardiac myocytes and perfused hearts
}

Citation for published version (APA):

Chabowski, A. M. I., Coort, S. L. M., Calles-Escandon, J. T. NN., Glatz, J. F., Luiken, J. J. F. P., \& Bonen, A. (2006). Prolonged AMPK activation increases the expression of fatty acid transporters in cardiac myocytes and perfused hearts. Molecular and Cellular Biochemistry, 288, 201-212. https://doi.org/10.1007/s11010-006-9140-8

Document status and date:

Published: 01/01/2006

DOI:

10.1007/s11010-006-9140-8

Document Version:

Publisher's PDF, also known as Version of record

\section{Document license:}

Taverne

Please check the document version of this publication:

- A submitted manuscript is the version of the article upon submission and before peer-review. There can be important differences between the submitted version and the official published version of record.

People interested in the research are advised to contact the author for the final version of the publication, or visit the DOI to the publisher's website.

- The final author version and the galley proof are versions of the publication after peer review.

- The final published version features the final layout of the paper including the volume, issue and page numbers.

Link to publication

\footnotetext{
General rights rights.

- You may freely distribute the URL identifying the publication in the public portal. please follow below link for the End User Agreement:

www.umlib.nl/taverne-license

Take down policy

If you believe that this document breaches copyright please contact us at:

repository@maastrichtuniversity.nl

providing details and we will investigate your claim.
}

Copyright and moral rights for the publications made accessible in the public portal are retained by the authors and/or other copyright owners and it is a condition of accessing publications that users recognise and abide by the legal requirements associated with these

- Users may download and print one copy of any publication from the public portal for the purpose of private study or research.

- You may not further distribute the material or use it for any profit-making activity or commercial gain

If the publication is distributed under the terms of Article $25 \mathrm{fa}$ of the Dutch Copyright Act, indicated by the "Taverne" license above, 


\title{
Prolonged AMPK activation increases the expression of fatty acid transporters in cardiac myocytes and perfused hearts
}

\author{
Adrian Chabowski, ${ }^{1}$ Iman Momken, ${ }^{1}$ Susan L.M. Coort, ${ }^{2}$ \\ Jorge Calles-Escandon, ${ }^{3}$ Narendra N. Tandon, ${ }^{4}$ Jan F.C. Glatz, ${ }^{2}$ \\ Joost J.F.P. Luiken ${ }^{2}$ and Arend Bonen ${ }^{1}$ \\ ${ }^{1}$ Department of Human Health and Nutritional Sciences, University of Guelph, Guelph, Ontario N1G 2W1, Canada; \\ ${ }^{2}$ Department of Molecular Genetics, Maastricht University, 6200-MD Maastricht, The Netherlands; ${ }^{3}$ Section of \\ Endocrinology and Metabolism, Wake Forest University School of Medicine and Baptist Medical Center, Winston-Salem, NC \\ 27157, U.S.A.; ${ }^{4}$ Thrombosis Research Laboratory, Otsuka Maryland Medicinal Laboratories, 9900 Medical Center Drive, \\ Rockville, MD 20850, USA
}

Received 7 November 2005; accepted 18 January 2006

\begin{abstract}
Recently, fatty acid transport across the plasma membrane has been shown to be a key process that contributes to the regulation of fatty acid metabolism in the heart. Since AMP kinase activation by 5-aminoimidazole-4-carboxamide-1- $\beta$-D-ribofuranoside (AICAR) stimulates fatty acid oxidation, as well as the expression of selected proteins involved with energy provision, we examined (a) whether AICAR induced the expression of the fatty acid transporters FABPpm and FAT/CD36 in cardiac myocytes and in perfused hearts and (b) the signaling pathway involved. Incubation of cardiac myocytes with AICAR increased the protein expression of the fatty acid transporter FABPpm after $90 \mathrm{~min}(+27 \%, P<0.05)$ and this protein remained stably overexpressed until $180 \mathrm{~min}$. Similarly, FAT/CD36 protein expression was increased after $60 \mathrm{~min}(+38 \%, P<0.05)$ and remained overexpressed thereafter. Protein overexpression, which occurred via transcriptional mechanisms, was dependent on the AICAR concentration, with optimal induction occurring at AICAR concentrations 1-5 mM for FABPpm and at 2$8 \mathrm{mM}$ for FAT/CD36. The AICAR ( $2 \mathrm{~h}, 2 \mathrm{mM}$ AICAR) effects on FABPpm and FAT/CD36 protein expression were similar in perfused hearts and in cardiac myocytes. AICAR also induced the plasmalemmal content of FAT/CD36 (+49\%) and FABPpm $(+42 \%)(P<0.05)$. This was accompanied by a marked increase in the rate of palmitate transport $(2.5$ fold $)$ into giant sarcolemmal vesicles, as well as by increased rates of palmitate oxidation in cardiac myocytes. When the AICAR-induced AMPK phosphorylation was blocked, neither FAT/CD36 nor FABPpm were overexpressed, nor were palmitate uptake and oxidation increased. This study has revealed that AMPK activation stimulates the protein expression of both fatty acid transporters, FAT/CD36 and FABPpm in (a) time- and (b) dose-dependent manner via (c) the AMPK signaling pathway. AICAR also (d) increased the plasmalemmal content of FAT/CD36 and FABPm, thereby (e) increasing the rates of fatty acid transport. Thus, activation of AMPK is a key mechanism regulating the expression as well as the plasmalemmal localization of fatty acid transporters. (Mol Cell Biochem 288: 201-212, 2006)
\end{abstract}

Key words: FAT/CD36, FABPpm, fatty acid transport, fatty acid oxidation, giant vesicles, perfusion

Address for offprints: A. Bonen, Department of Human Health and Nutritional Sciences, University of Guelph, Guelph, Ontario N1G 2W1, Canada (E-mail: abonen@uoguelph.ca) 
Long chain fatty acids (LCFAs) are the principal myocardial energy substrate [1]. AMP kinase (AMPK) has been implicated to play an important regulatory role in cardiac myocyte fatty acid oxidation [2,3]. Active forms of AMP kinase cause phosphorylation of ACC (acetyl-CoA carboxylase), resulting in its inactivation with a concomitant decrease in the intracellular levels of malonyl-CoA $[4,5]$. In cardiac myocytes [6], and in muscle [7-9], the reduction of malonyl-CoA reduces the inhibition on carnitine palmitoyl-transferase-1 (CPT-1), thereby promoting the increase in mitochondrial fatty acid uptake and oxidation. Recently, it was also proposed that AMPK activation may stimulate cardiac LCFA oxidation by increasing the rate of LCFA uptake across the plasma membrane in the isolated working heart [10] or in vivo [11]. However, definitive mechanisms were not examined.

The synthesis or storage of LCFAs is a limited process in heart [12], and therefore, this tissue is highly dependent on the blood borne delivery of LCFAs. It is now well-documented that LCFA uptake in many tissues [13-16], including the heart $[17,18]$, is facilitated by fatty acid transporters. Several fatty acid transporters are expressed in heart, including fatty acids translocase (FAT/CD36), plasma membrane associated fatty acid binding protein (FABPpm) and fatty acid transporter 1 (FATP-1) [18-22], although it has recently been shown that FATP-6 is present in far greater quantities in the heart than FATP-1 [23]. The molecular mechanisms by which these proteins move LCFAs across the plasma membrane are not yet clear. These proteins may function in trapping LCFAs, and transmembrane translocation occurs by flip-flop [24]. Despite not knowing precisely how protein-mediated LCFA trafficking occurs across the plasma membrane, there is strong experimental evidence for the involvement of FAT/CD36 and FABPpm in this process. Work in our laboratory has shown that the expression of FABPpm and FAT/CD36 and their subcellular distribution, as well as LCFA transport, are regulated acutely and chronically by selected physiologic stimuli [13, $17,18,20,22,25]$.

Acute stimulation of LCFA transport can occur within minutes in heart and skeletal muscle, and is stimulated by insulin $[17,22]$ as well as by contraction [13, 18]. This increase in LCFA uptake is attributable to insulin-, and contractioninduced translocation of FAT/CD36 to the plasma membrane [13, 17, 18, 22]. However, insulin stimulation (30 min) failed to stimulate the translocation of FABPpm from an intracellular depot to the plasma membrane [26], whereas the 5-aminoimidazole-4-carboxamide 1- $\beta$-D-ribofuranoside (AICAR)-stimulated activation of AMPK (30 min) induced the translocation of both FABPpm and FAT/CD36 [26], from an intracellular depot to the plasma membrane. Thus, under acute stimulation $(\leq 30 \mathrm{~min})$, and in the absence of their altered expression, FABPpm and FAT/CD36 exhibit differential responsiveness to selected metabolic stimuli.
Chronic regulation (hours-days) of LCFA transport and transporters has also been shown. Within $2 \mathrm{~h}$, insulin upregulates the protein expression of FAT/CD36, but not FABPpm, in cardiac myocytes [20]. This insulin-induced overexpression of FAT/CD36 and its concomitant translocation to the plasma membrane were positively correlated with the increased rates of fatty acid transport into the heart [20]. Increased muscle activity (chronic muscle stimulation for 7 days) also upregulated the protein expression and plasmalemmal content of both FAT/CD36 and FABPpm, and increased the rate of LCFA transport [27, 28]. In contrast, denervation of muscle (7 days), which eliminates muscle activity and induces marked changes in the expression of many genes [29], failed to alter FABPpm and FAT/CD36 protein expression. However, the plasmalemmal content of these proteins was reduced, as was the rate of LCFA transport [28]. Thus, it appears that prolonged stimulation with insulin and prolonged changes in muscle activity can alter the expression and/or subcellular distribution of FABPpm and FAT/CD36 in heart or skeletal muscle, with concurrent changes in LCFA transport.

Contractile activity is known to activate of AMP kinase (AMPK), and it is thought that phosphorylation of this kinase is central to the contraction-induced upregulation of fatty acid oxidation as well as the expression of selected metabolic genes (cf [30]). For example, (a) aminoimidazole4-carboxamide-1- $\beta$-D-ribofuranoside (AICAR)-stimulated AMPK activation acutely (30-60 min) increases LCFA oxidation in the absence of any changes in protein expression [31, 32], and (b) prolonged (hours - weeks) AMPK activation by AICAR is a key stimulus for increasing the expression of metabolic proteins in skeletal muscle, including UCP3, PGC$1 \alpha$, MCT4, GLUT4, citrate synthase, 3-hydroxyacyl-CoA dehydrogenase [33-35]. However, it is not known whether prolonged AMPK activation induces the expression of selected metabolic genes in the heart as has been observed in skeletal muscle. There is some evidence that AMPK activation has tissue-specific effects [36]. In recent years it has been suggested cardiac fatty acid metabolism in vivo is influenced by the uptake of LCFAs [3,10,11], a process that is mediated by fatty acid transporters in the heart (cf. [37, 38]). In view of the key role of AMPK activation of gene expression in muscle, we hypothesized that AMPK activation, when prolonged, also regulates the expression of the fatty acid transporters FAT/CD36 and FABPpm in the heart, which would be expected to increase the transport rate of LCFAs and their subsequent oxidation. Specifically, we examined (a) the time- and dose-dependent effects of AICAR on FABPpm and FAT/CD36 protein expression in cardiac myocytes, (b) whether the effects of AICAR on FABPpm and FAT/CD36 protein expression were similar in cardiac myocytes and in the perfused heart, (c) whether the AICARinduced upregulation of FAT/CD36 and FABPm increased their plasmalemmal content, thereby increasing myocardial 
LCFA transport, leading to an increase in LCFA oxidation, and finally, (d) we also examined whether the inhibition of AMPK activation, as well as other signaling pathways, prevented the increased expression of FAT/CD36 and FABPpm, as well as inhibiting the increase in LCFA uptake and oxidation.

\section{Methods}

\section{Materials}

The PI3 kinase inhibitor (LY 294002) and MEK1/2 kinase inhibitor (UO126) were purchased from Cell Signaling Technology (Beverly, MA). PKC $\zeta / \lambda$ inhibitor (myristoylated PKC $\zeta / \lambda$ pseudosubstrate was purchased from Calbiochem (San Diego, CA) and ARA (adenine 9- $\beta$-D-arabinofuranoside) was obtained from Sigma-Aldrich (St. Louis, MO). Antibodies used in this study were as follows: MO25 was used to detect FAT/CD36 [39]] and FABPpm antisera was used to detect FABPpm [40]. Total and phosphorylated quantities of selected proteins were determined with commercially available antibodies (Akt kinase: anti-Akt1/2/3 and antiphospho-Akt1/2/3 (Ser 473 or Thr 308), Santa Cruz Biotechnology, (Santa Cruz, CA); MAP kinase: anti-p42/44 ERK1/2, anti-phospho-p42/44 ERK1/2 (Thr202/Thr 204) and antipMEK1/2 (Ser 217/221) Cell Signaling Technology (Beverly, MA); PKC $\zeta / \lambda$ kinase: anti- PKC $\zeta / \lambda$ and rabbit antiphospho-PKC $\zeta / \lambda$ (Thr410/403), Cell Signaling Technology (Beverly, MA); AMP kinase: anti-phospho-AMPK (Thr 174), rabbit anti-AMPK, anti-phospho-ACC (Ser 79), Cell Signaling Technology (Beverly, MA). Goat-anti-rabbit secondary antibodies were purchased from Santa Cruz Biotechnology (Santa Cruz, CA). $\left[1-{ }^{14} \mathrm{C}\right]$-palmitate was purchased from Amersham Life Science (Little Chalfont, UK). BSA (fraction V, essentially FA free (confirmed in separate analyses)) and phloretin were obtained from Sigma-Aldrich (St. Louis, MO). Collagenase type II was purchased from Worthington (Lakewood, NJ, U.S.A.). The cell-permeate adenosine analog, 5-aminoimidazole-4-carboxamide-1-b-Dribofuranoside (AICAR), was purchased from Toronto Research Chemicals Inc., (North York, ON, Canada). All other chemicals were obtained from Sigma-Aldrich (St. Louis, MO).

\section{Animals and cardiac myocytes isolation}

Male Wistar rats (250-300 g) were bred on site and maintained at $20^{\circ} \mathrm{C}$ on a reverse light-dark cycle in approved animal holding facilities. The animals had unrestricted access to food and water. This study was approved by the committee on animal care at the University of Guelph.
Cardiac myocytes were isolated from male adult rats according to the procedure previously described by us $[18$, 20, 22] based on procedures developed by Fischer et al. [41]. Briefly, rats were anaesthetized using Somnotol (50$60 \mathrm{mg} / 100 \mathrm{~g}$, i.p.) combined with heparin (300 i.u./100 g, i.p.). The hearts were quickly removed and placed in icecold Krebs-Henseleit bicarbonate buffer, (KHB, pH 7.4), and equilibrated with $95 \% \mathrm{O}_{2}$ and $5 \% \mathrm{CO}_{2}$. Subsequently, hearts were perfused $(20 \mathrm{~min})$ in a recirculating mode, with KHB buffer supplemented with $0.7 \%$ (w/v) BSA, $15 \mathrm{mM}$ butanedione monoxime and $0.075 \%(\mathrm{w} / \mathrm{v})$ collagenase type II. $\mathrm{CaCl}_{2}$ was added to a final concentration $0.2 \mathrm{mM}$ during the perfusion. After $20 \mathrm{~min}$ hearts were removed and gently minced. The suspension was incubated for another $10 \mathrm{~min}$ at $37^{\circ} \mathrm{C}$, while the $\mathrm{CaCl}_{2}$ concentration was gradually raised to $1.0 \mathrm{mM}$. Then cells were filtered through $0.2 \mathrm{~mm}$ nylon gauze and centrifuged for $2 \mathrm{~min}$ at $20 \times \mathrm{g}$. After isolation, cells were washed twice and suspended in $20 \mathrm{ml}$ of medium A (KHB buffer supplemented with $2 \%(\mathrm{w} / \mathrm{v}) \mathrm{BSA}$ and $1 \mathrm{mM} \mathrm{CaCl} 2$ ). At the beginning of the experiments the percentage of rod-shaped cells excluding trypan blue was determined. For all the experiments $\geq 80 \%$ of the cardiac myocytes were structurally intact. For determination of cardiac myocytes wet mass, duplicate aliquots of the cells suspensions were centrifuged $(2-3$ sec., at $10,000 \times g)$. The yield of cardiac myocytes ranged from 500-600 mg per single heart.

\section{Effects of AICAR on FABPpm and FAT/CD36}

To examine the effects of AICAR on cardiac myocytes FABPpm and FAT/CD36 expression, we performed timeand dose- dependent studies. After the isolation, cardiac myocytes were incubated in medium A with or without additions of AICAR ( $2 \mathrm{mM}$, unless otherwise stated). All studies were performed at $37^{\circ} \mathrm{C}$ and cardiac myocytes viability was $>80 \%$ for $3 \mathrm{~h}$ (data not shown). The time course studies (2 mM AICAR, 0 min-180 min) and dose response studies (0-8 mM AICAR, $120 \mathrm{~min}$ ) were performed to examine the effects of AICAR on FAT/CD36 and FABPpm expression. At the end of the experiments cardiac myocytes were washed twice with PBS buffer and prepared for Western blotting as previously described [20].

To ascertain the signaling pathways that are involved in the AICAR-induced regulation of the LCFA transporter proteins, cardiac myocytes were pretreated for $1 \mathrm{~h}$ with selected inhibitors, followed by treatment with AICAR ( $2 \mathrm{mM}, 120 \mathrm{~min}$ ). The inhibitors used were as follows: AMP kinase competitive inhibitor: ARA ( $2.5 \mathrm{mM})$ (adenine $9-\beta$-Darabino-furanoside) [42, 43]; PKC-ps: myristoylated Protein Kinase $\mathrm{C} \zeta / \lambda$ pseudosubstrate inhibitor, $(10 \mu \mathrm{M})$, which has been used as a cell-permeable specific inhibitor of PKC $\zeta / \lambda$ 
kinases [44]; UO 126 has been used at a concentration of $10 \mu \mathrm{M}$ as a highly selective inhibitor of the MAP kinases, MEK1 and MEK2 [45]; and finally, LY294002 was shown to act as highly selective inhibitor of phosphatidylinositol 3 kinase (PI3K), and at a concentration of $50 \mu \mathrm{M}$ does not inhibit lipid and protein kinases such as PI 4 kinase, PKC, MAP kinase or c-Src [46].

\section{Effects of AICAR on LCFA uptake and oxidation by cardiac myocytes}

To examine the effects of AICAR $(2 \mathrm{mM})$ exposure on initial rates of palmitate uptake by cardiac myocytes we used the procedure of Luiken et al [12, 18, 22]. For these purposes $0.6 \mathrm{ml}$ of a $\left[1-{ }^{14} \mathrm{C}\right]$ palmitate-BSA complex was added to $1.8 \mathrm{ml}$ of cardiac myocyte suspension at the end of the incubation period, (final palmitate concentration $100 \mu \mathrm{M}$, palmitate/BSA ratio of 0.3). Palmitate uptake was stopped after 3 min by adding an ice-cold stop solution (KHB buffer supplemented with $0.1 \% \mathrm{BSA}(\mathrm{w} / \mathrm{v}), 1 \mathrm{mM} \mathrm{CaCl} 2$ and $0.2 \mathrm{mM}$ phloretin). Subsequently, cells were washed twice $(60 \times g$ for $2 \mathrm{~min}$ ) with the stop solution. The final pellet was assayed for radioactivity.

Rates of palmitate oxidation were determined under the same experimental conditions, using procedures that we have described previously [47, 48]. Briefly, $30 \mathrm{~min}$ before the end of the incubation period, $0.6 \mathrm{ml}$ of a $\left[1-{ }^{14} \mathrm{C}\right]$ palmitateBSA complex was added to $1.8 \mathrm{ml}$ of cardiac myocytes suspension, (final palmitate concentration $100 \mu \mathrm{M}$, palmitate/BSA ratio of 0.3 ). During the final $30 \mathrm{~min}$ of incubation ${ }^{14} \mathrm{CO}_{2}$ was trapped in benzothium hydroxide and assayed for radioactivity.

\section{Heart perfusion, giant vesicles preparation and LCFA transport}

Isolated hearts were perfused with or without AICAR ( $2 \mathrm{mM}$, $120 \mathrm{~min}$ ), in the Langendorff mode, using continuously gassed $\left(95 \% \mathrm{O}_{2}-5 \% \mathrm{CO}_{2}\right)$ medium $\mathrm{A}$ as we $[18,20,26,47]$ have previously reported. After $2 \mathrm{~h}$, the ventricles were removed and were frozen in liquid nitrogen and stored at $-80^{\circ} \mathrm{C}$ until analyzed for FAT/CD36 and FABPpm using Western blotting.

Hearts perfused with and without $\operatorname{AICAR}(2 \mathrm{mM}, 120 \mathrm{~min})$ were also used to examine LCFA transport into giant vesicles. After $2 \mathrm{~h}$ of perfusion the ventricles were removed and placed in $\mathrm{KCl} / \mathrm{MOPS}$ buffer (140 mM KCl, $10 \mathrm{mM}$ MOPS, $\mathrm{pH}$ 7.4). To prepare giant sarcolemmal vesicles we used procedures reported previously $[20,49]$. Briefly, perfused ventricles were scored into strips with a scalpel and incubated for $1 \mathrm{~h}$ at $34{ }^{\circ} \mathrm{C}$ in $\mathrm{KCl} / \mathrm{MOPS}$ buffer supplemented with $0.142 \mathrm{mg} / \mathrm{mL}$
PMSF, $1.0 \mathrm{mg} / \mathrm{mL}$ aprotinin, and $150 \mathrm{U} / \mathrm{mL}$ type II collagenase. The incubation medium was collected and the ventricles were washed with $10 \mathrm{mM}$ EDTA in $\mathrm{KCl} / \mathrm{MOPS}$ until $7 \mathrm{~mL}$ had been collected. Percoll was added to the collected medium in a volume ratio of 7:30. This mixture was slowly pipetted under a density gradient of $3 \mathrm{ml} 4 \% \mathrm{w} / \mathrm{v}$ Nycodenz, on top of which $1 \mathrm{~mL} \mathrm{KCl/MOPS} \mathrm{was} \mathrm{layered.} \mathrm{The} \mathrm{sam-}$ ples were centrifuged in a swinging bucket rotor (Beckman) at $60 \times g$ for $45 \mathrm{~min}$ at room temperature. After centrifugation, the vesicles were collected from the interface between the Nycodenz and $\mathrm{KCl} / \mathrm{MOPS}$ solutions. The vesicles were pelleted at $12000 \times g$ for $5 \mathrm{~min}$ at room temperature. The supernatant was aspirated and the vesicles slightly diluted with $\mathrm{KCl} / \mathrm{MOPS}$ supplemented with PMSF. Vesicles were used immediately for LCFA transport. Some vesicles were also stored at $-80{ }^{\circ} \mathrm{C}$ until analyzed for plasmalemmal fatty acid transporters.

LCFA transport was performed as we have previously reported [22, 49]. Briefly, a reaction medium (unlabelled palmitate, radiolabelled $\left[{ }^{3} \mathrm{H}\right]$-palmitate $(0.3 \mu \mathrm{Ci}$, $)$ and $\left[{ }^{14} \mathrm{C}\right]-$ mannitol $(0.06 \mu \mathrm{Ci})$ dissolved in $0.1 \% \mathrm{BSA}-\mathrm{KCl} / \mathrm{MOPS}$ solution) was added to the vesicles (40-80 $\mu$ g protein) and incubated for $15 \mathrm{~s}$ at room temperature. A stop solution $(2.5 \mathrm{mM}$ $\mathrm{HgCl}$ in $0.1 \% \mathrm{BSA}-\mathrm{KCl} / \mathrm{MOPS}$ ) was added and the sample immediately centrifuged $(12000 \times g, 2 \mathrm{~min})$. The supernatant fraction was aspirated and the bottom of the tube containing the pellet was cut off and placed in a scintillation vial. Standard liquid scintillation techniques were used to measure the radioactivity.

\section{Western blotting}

At the end of the experiments total FAT/CD36 and FABPpm protein expression was determined in cardiac myocytes and perfused intact hearts. For these purposes cardiac myocytes were washed twice with PBS buffer and homogenized and re-suspended in Buffer 2 (Tris-base $10 \mathrm{mM}$, EDTA $1 \mathrm{mM}$, $\mathrm{pH}$ 7.4) and frozen in liquid nitrogen. From perfused hearts, homogenates yielding crude membranes were prepared as described previously $[20,26]$. FAT/CD36 and FABPpm were also determined in PM and LDM fractions from subfractionated cardiac myocytes, as well as in plasma membranes from giant vesicles obtained from perfused hearts. Routine Western blotting procedures were used to detect proteins as described previously [18, 20, 22]. Protein content was determined with bicinchonic acid method with BSA serving as a protein standard. Briefly, all samples were separated using $10 \%$ SDS-polyacrylamide gel electrophoresis and polyclonal antiserum was applied. Signals obtained by Western blotting were quantified by densitometry using chemiluminescence and the ChemiGenius2 bioimaging system (SynGene, $\mathrm{UK})$. 


\section{Northern blotting}

Total RNA was isolated from cardiac myocytes using TriPure Isolation Reagent (Roche, Indianapolis, IN). 3-5 $\mu \mathrm{g}$ of the total RNA was loaded on a formaldehyde gel for each sample, electrophoresed at $100 \mathrm{~V}$ for $2.5 \mathrm{~h}$ and transferred to positively charged nylon membranes (Roche, Indianapolis, IN). Equal loading of RNA and even transfers were confirmed by Blot Stain Blue (Sigma-Aldrich, Oakville, ON). FAT/CD36 and FABPpm DIG labelled probes were generated using a digoxigenin (DIG) RNA labelling mix (Roche, Indianapolis, IN). Membranes were prehybridized for 30$60 \mathrm{~min}$ at $68{ }^{\circ} \mathrm{C}$ in a standard hybridization buffer (containing $25 \%$ (FAT/CD36) or 50\% (FABPpm) deionized formamide, $5 \times \mathrm{SSC}, 0.1 \% \mathrm{~N}$-lauroyl-sarcosine, $0.02 \% \mathrm{SDS}$, and $2 \times$ Blocking Solution (Roche, Indianapolis, IN). Membranes were hybridized overnight at $68^{\circ} \mathrm{C}$ in $1 \mu \mathrm{g}$ of DIG labelled probe per $10 \mathrm{ml}$ of hybridization buffer. Membranes were washed, blocked in 1X Blocking Solution for $30 \mathrm{~min}$ and incubated with anti-Digoxigenin-AP antibody (1:10 000) for $30 \mathrm{~min}$. Signal detection was performed using CDP-Star chemiluminescent substrate (Roche, Indianapolis, IN). Blots were visualized and quantified using the ChemiGenius ${ }^{2}$ Bio Imaging System (Perkin Elmer, Boston).

\section{Statistics}

All presented data are expressed as mean \pm S.E.M. Depending on the experiment, statistical differences were tested with either a $t$-test or with an analysis of variance and Fisher's least squares differences post-hoc test. Statistical significance was set at $P \leq 0.05$.

\section{Results}

Dose and time dependent effects of AICAR on cardiac myocyte FABPpm and FAT/CD36

We exposed freshly isolated cardiac myocytes to AICAR $(2 \mathrm{mM})$ for up to $3 \mathrm{~h}$. At selected time points the cells were harvested. In control experiments (no AICAR), FAT/CD36 and FABPpm proteins were not altered during the incubation period (Fig. 1A). In contrast, in the presence of AICAR, the expression of both FAT/CD36 and FABPpm was increased during the $3 \mathrm{~h}$ incubation period. No changes were observed within first $30 \mathrm{~min}$, but after $60 \mathrm{~min}(+12 \%)$ and 90 min $(+27 \%)$ FABPpm protein was increased $(P<0.05)$ and FABPpm upregulation remained quite stable from 60 $150 \mathrm{~min}$ (Fig. 1A, $P<0.05$ ). FAT/CD36 was also increased after $60(+38 \%)$ and $90 \mathrm{~min}(+44 \%)$ (Fig. 1A, $P<0.05)$. This protein also remained stably upregulated.
With increasing AICAR concentrations we observed a dose-dependent increase in the expression of both FAT/CD36 and FABPpm proteins. Both FAT/CD36 and FABPpm proteins increased progressively as the concentration of AICAR was increased $(0-8 \mathrm{mM}$, Fig. $1 \mathrm{~B}, P<0.05)$ attaining a plateau at the concentration of $1-5 \mathrm{mM}$ for FABPpm and 2-8 mM for FAT/CD36 (Fig. 1B). During this time, AICAR ( $2 \mathrm{mM}, 120 \mathrm{~min}$ ) exposure increased both FABPpm mRNA $(+238 \%)$ and FAT/CD36 mRNA $(+159 \%) \quad(P<0.05$, Fig. 2)

\section{Effects of AICAR on LCFA transporters FABPpm and FAT/CD36 in intact hearts}

To determine whether AICAR-induced upregulation of both LCFA transporters in cardiac myocytes also occurs in intact hearts, we examined the effect of AICAR in Langendorff perfused hearts. Perfusion of the hearts for $2 \mathrm{~h}$ with AICAR $(2 \mathrm{mM})$ increased both FABPpm $(+23 \%)$ and FAT/CD36 $(+36 \%)$ protein expression $(P<0.05$, Fig. 3A). Similar AICAR-induced increments were also observed for FABPpm $(+27 \%)$ and FAT/CD36 $(+44 \%)$ in cardiac myocytes $(P<$ 0.05, Fig. 3B).

\section{Effects of AICAR on LCFA transporters and transport into giant vesicles}

To examine whether the AICAR-induced effects on fatty acids transporters can alter LCFA transport into the heart, we determined the rate of LCFA transport into giant vesicles derived from the $2 \mathrm{~h}$ AICAR-perfused hearts. In the AICAR-perfused hearts the rates of palmitate transport into giant vesicles were significantly elevated (2.5 fold, Fig. 4A, $P<0.05)$. This was associated with concomitant increases in both FABPpm and FAT/CD36 at the plasma membranes after $2 \mathrm{~h}$ exposure to AICAR $(+42 \%$ and $+49 \%$, respectively, Fig. 4B, $P<0.05)$.

\section{Signaling pathways involved in AICAR-induced FABPpm and FAT/CD36 overexpression}

We examined possible signaling pathways involved in the AICAR-induced FAT/CD36 and FABPpm upregulation in cardiac myocyte. As has been shown previously $[18,50]$, exposure of cardiac myocytes to AICAR ( $2 \mathrm{mM}, 15 \mathrm{~min}$.) increased the ACC and AMPK phosphorylation (Fig. 5A and B, 4.5 fold and 1.9 fold, respectively). As reported elsewhere $[18,50]$, AICAR also induced the phosphorylation of MEK1/2 (4.9 fold data not shown), ERK1/2 (1.7 fold, data not shown) and PKC $\zeta / \lambda$ (1.7 fold, data not shown). AICAR 

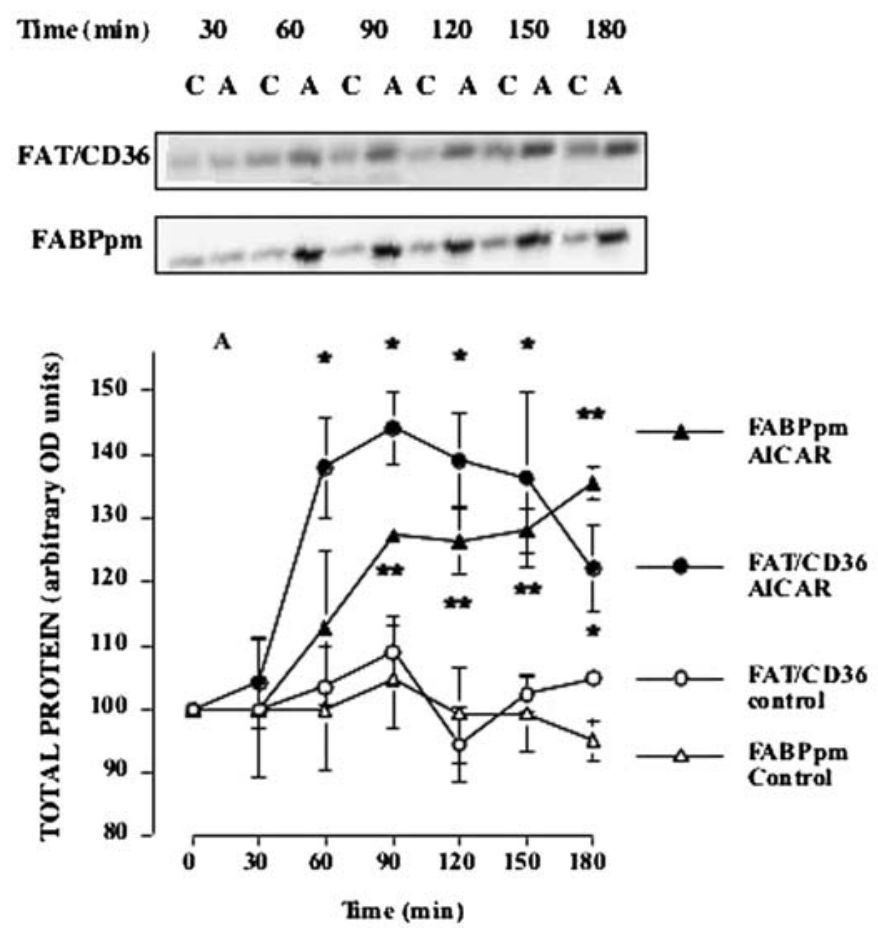

$\begin{array}{llllllll}\text { Dose }(\mathrm{mM}) & 0.002 & 0.02 & 0.2 & 1 & 2 & 4 & 8\end{array}$

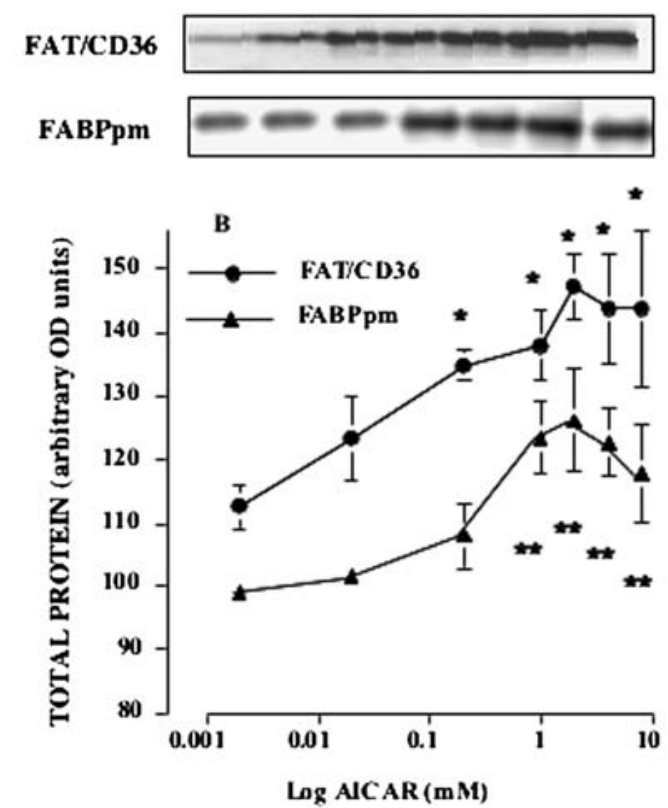

Fig. 1. Time dependent (0-180 min) effects of AICAR ( $2 \mathrm{mM})(\mathrm{A})$ and dose $(0-8 \mathrm{mM}, 2 \mathrm{~h})$ response effects of AICAR (B) on FAT/CD36 and FABPpm protein expression in cardiac myocytes. (mean \pm sem). Panel $A$ : For the time course studies, cardiac myocytes were prepared from rat hearts and incubated for varying periods of time at $37^{\circ} \mathrm{C}$ in the absence and presence of AICAR. Data are based on 4 independent determinations at each time point. ${ }^{*} P<0.05$, FAT/CD36: AICAR vs control at each time point. ${ }^{* *} P<0.05$, FABPpm: AICAR vs control at each time point. Panel B: For the dose response studies, cardiac myocytes were prepared from rat hearts and incubated for $2 \mathrm{~h}$ at $37^{\circ} \mathrm{C}$ in the absence and presence of AICAR. Data are based on $6-11$ independent determinations at each concentration. Note the log scale. Reference points for FAT/CD36 and FABPpm are $100 \%$ in the absence of AICAR. ${ }^{*} P<0.05$, FAT/CD36: AICAR vs no AICAR. ${ }^{* *} P<0.05$, FABPpm: AICAR vs no AICAR.

did not induce the phosphorylation of Akt (ser 473, data not shown), as previously observed [51].

To establish the signalling pathways that could potentially be involved in regulating FABPpm and FAT/CD36 expression, selected specific inhibitors were used to block phosphorylation of Akt, AMPK, MEK1/2 and PKC $\zeta / \lambda$. These studies showed that it was possible to block (a) AICARinduced phosphorylation of AMPK and ACC by adenine 9$\beta$-D-arbino-furanoside (ARA) (Fig. 5A and B), and (b) to block the AICAR-induced phosphorylation of PKC $\zeta / \lambda$ kinases by myristoylated protein kinase $\mathrm{C} \zeta / \lambda$ pseudosubstrate (PKC-ps) and MEK1/2 by UO 126 (data not shown). However, blocking the phosphorylation of MEK1/2 and PKC $\zeta / \lambda$ did not affect the AICAR-induced expression of FABPpm and FAT/CD36 (data not shown). In contrast, the AICAR-induced increase in the expression of both FABPpm and FAT/CD36 was completely inhibited (Fig. 6A and B), when the AMPK signalling pathway was blocked by ARA. Correspondingly, at the functional level, $2 \mathrm{~h}$ AICAR exposure stimulated the uptake and oxidation of palmitate by cardiac myocytes (Fig. 6C and D). However, when the AICAR-induced phosphorylation of AMPK was blocked by ARA, palmitate uptake and oxidation into cardiac myocytes were also blocked (Fig. 6C and D).

\section{Discussion}

We have previously shown that AICAR induces the translocation of FAT/CD36 and FABPpm, but not FATP1 [26]. In those studies we were careful to establish that protein expression was not altered, by maintaining only a short duration exposure to AICAR (30 min) [26]. In the present studies there was a very different focus. Specifically, we examined whether AICAR induced the expression of FAT/CD36 and FABPpm, the signalling pathway involved, and the effects of upregulating FAT/CD36 and FABPpm on LCFA transport.

Our present studies have provided evidence for a novel role for AICAR-induced AMPK activation in the regulation of protein-mediated LCFA entry into the heart. We found (a) that AICAR very rapidly induced (i) the overexpression of both FAT/CD36 and FABPpm at the mRNA level and (ii) upregulated both FABPpm and FAT/CD36 proteins in a 

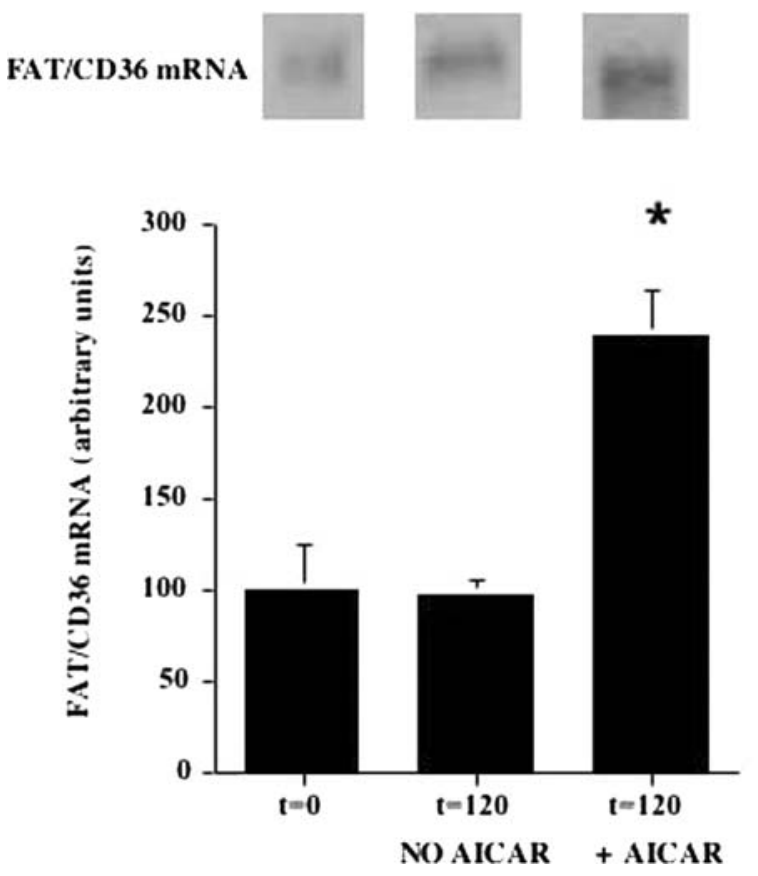

FABPpm mRNA
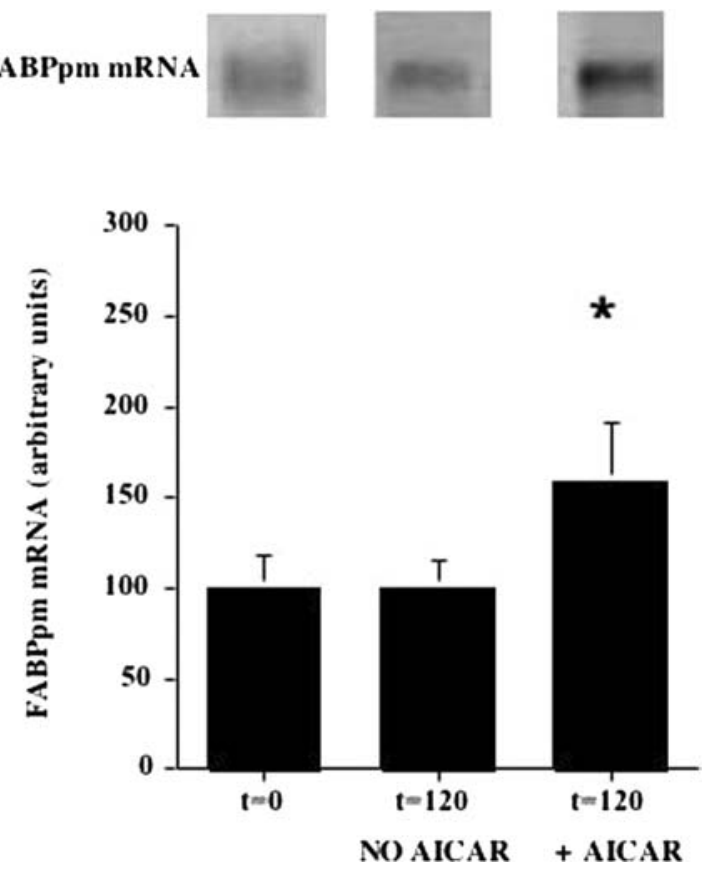

Fig. 2. Effects of AICAR on FAT/CD36 mRNA (A) and FABPpm mRNA (B) in cardiac myocytes. Cardiac myocytes were prepared from rat hearts and incubated for $2 \mathrm{~h}$ at $37^{\circ} \mathrm{C}$ in the absence and presence of AICAR $(2 \mathrm{mM})$. Data are based on 3-4 independent determinations at each time point (mean \pm sem). ${ }^{*} P<0.05$ AICAR-treated cardiac myocytes at $120 \mathrm{~min} v s$ control cardiac myocytes at $t=0$ and $120 \mathrm{~min}$.

A

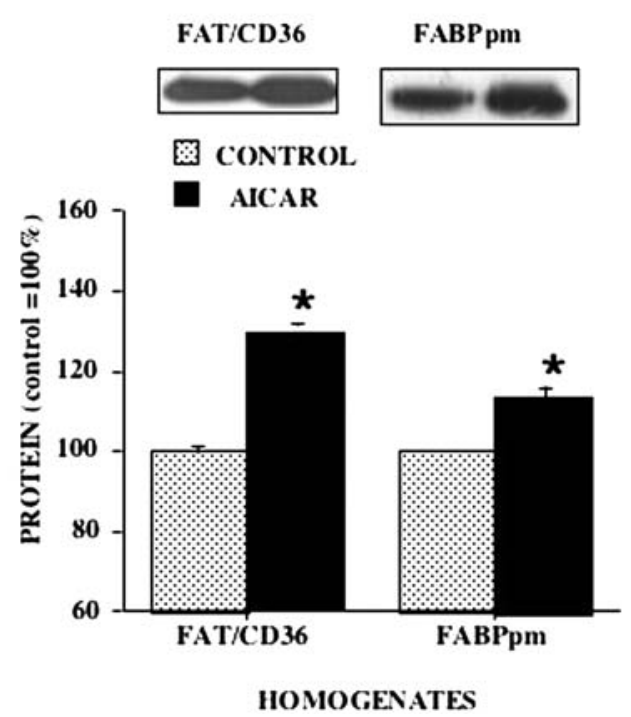

B

CARDLAC MYOCYTES

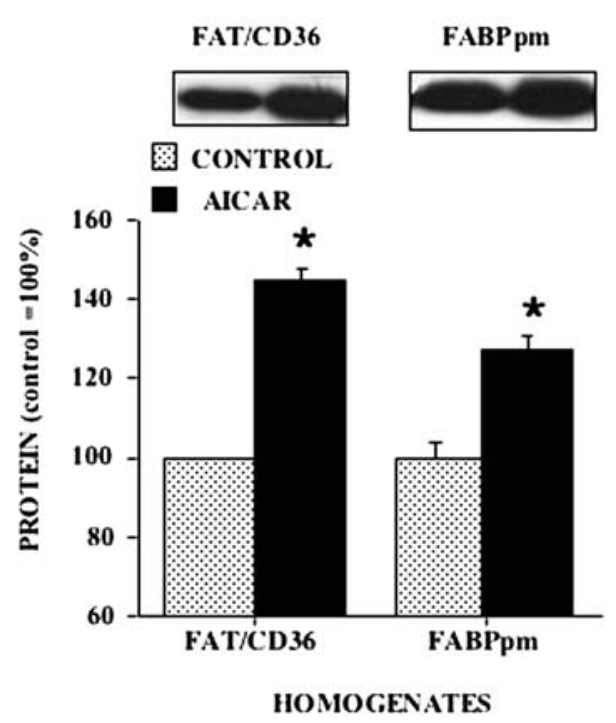

Fig. 3. Comparison of the effects of AICAR on FAT/CD36 and FABPpm protein expression in Langendorff perfused hearts (A) and in cardiac myocytes (B). Hearts were perfused for 2 hours at $37^{\circ} \mathrm{C}$ in Langendorff mode in the absence and presence of AICAR ( 2 mM). Cardiac myocytes were prepared from rat hearts and incubated for $2 \mathrm{~h}$ at $37^{\circ} \mathrm{C}$ in the absence and presence of AICAR $(2 \mathrm{mM})$. Data are based on 4 independent determinations for perfused hearts and cardiac myocytes (mean \pm sem). ${ }^{*} P<0.05$, AICAR $v$ s control.

time- and dose-dependent manner, (b) the AICAR-induced expression of both LCFA transport proteins was quantitatively similar in cardiac myocytes and in the intact, Langendorff perfused hearts, (c) AMPK activation not only increased
LCFA transporter expression, but AMPK activation also targeted these transporters to the plasma membrane, (d) this increase in plasmalemmal FA transporters was associated with an increased the rate of LCFA transport into the heart, 


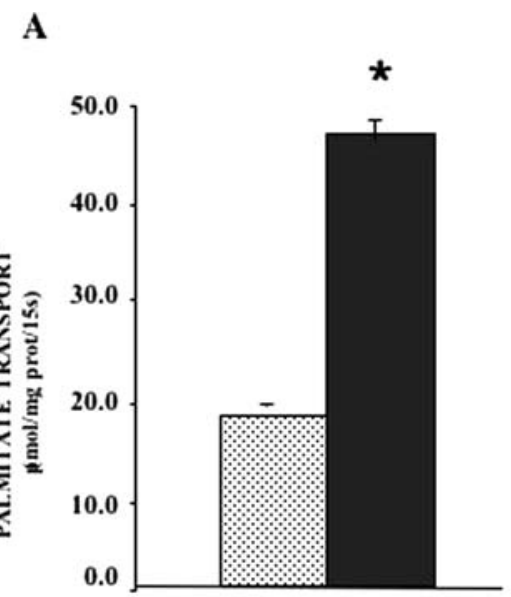

Transport into Giant Vesicles
B

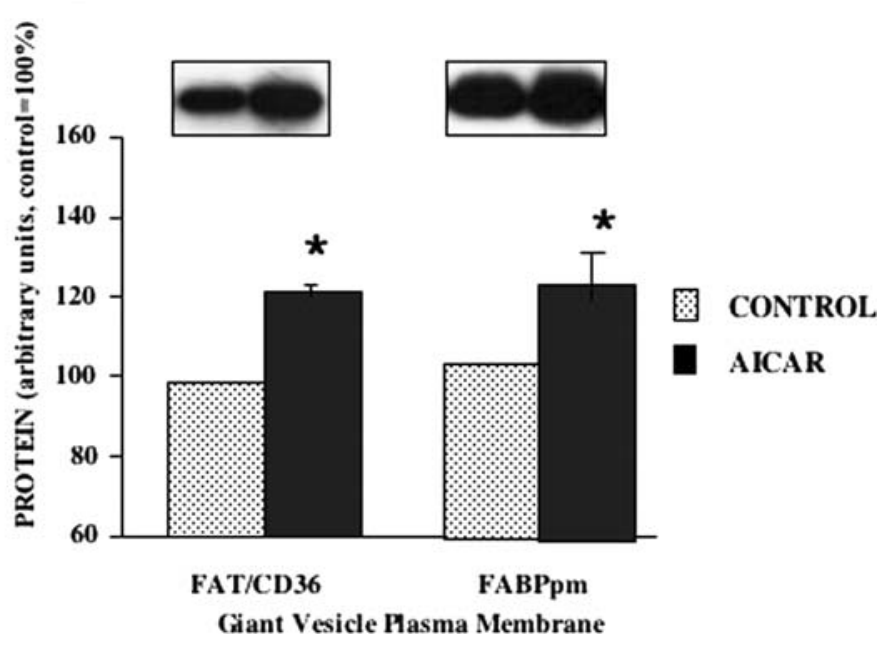

Fig. 4. Effects of AICAR on (A) the rates of palmitate transport into giant vesicles and (B) plasmalemmal FAT/CD36 and FABPpm proteins. Hearts were perfused in Langendorff mode at $37^{\circ} \mathrm{C}$ for $2 \mathrm{~h}$ in the absence and/or presence of AICAR $(2 \mathrm{mM})$. Thereafter, the rates of palmitate transport into giant vesicles were determined and Western blotting was performed on plasma membranes derived from the giant vesicles. Data are based on 3-4 independent determinations for each treatment (mean \pm sem). ${ }^{*} P<0.05$, AICAR vs control.

\section{A}

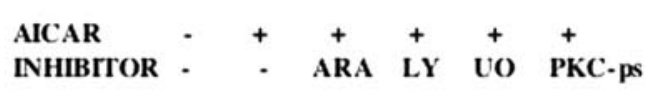

B

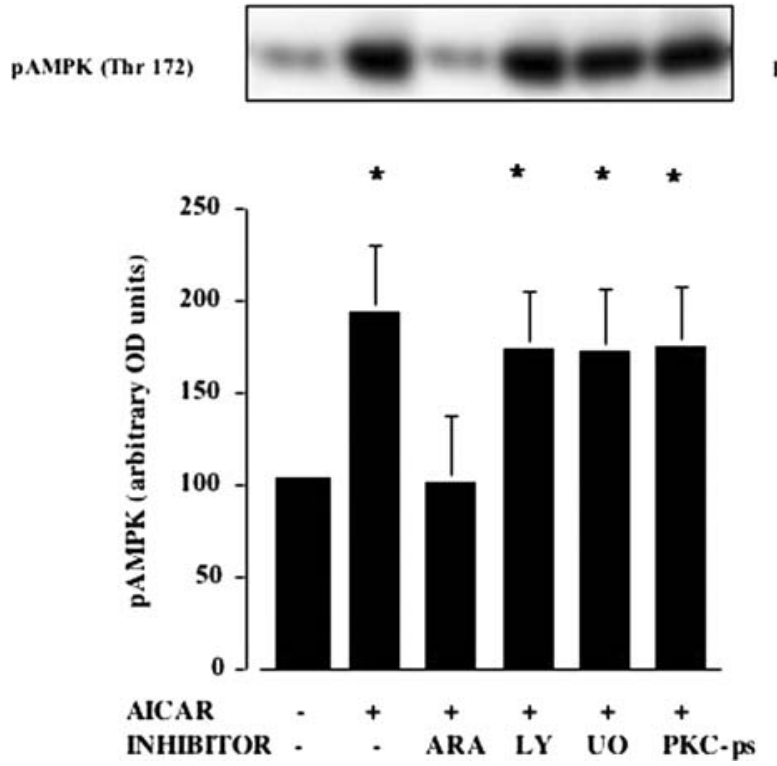

PACC (Ser 79)
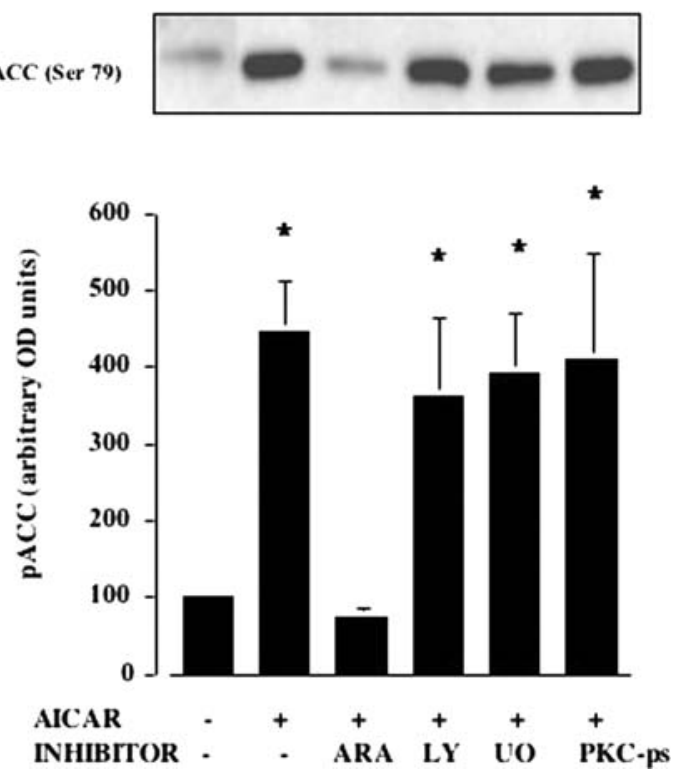

Fig. 5. Effects of AICAR and AICAR + selected inhibitors on the phosphorylation of AMPK and ACC proteins. Data are based on 3 independent determinations for each treatment (mean $\pm \mathrm{sem}$ ). ${ }^{*} P<0.05$, treatment $v s$ control. Cardiac myocytes, prepared from rat hearts, were preincubated for $1 \mathrm{~h}$ at $37^{\circ} \mathrm{C}$, in the absence and/or presence of inhibitors, followed by incubation with AICAR $(2 \mathrm{mM})$ for $15 \mathrm{~min}$. The inhibitors used were as follows: ARA (10 $\mu \mathrm{M}$, adenine 9- $\beta$-D-arabino-furanoside), PKC-ps (10 $\mu \mathrm{M}$, myristoylated Protein Kinase $\mathrm{C} \zeta / \lambda$ pseudosubstrate inhibitor); UO 126 (10 $\mu \mathrm{M}$ inhibitor of the MAP kinases); LY294002 (50 $\mu \mathrm{M}$ inhibitor of phosphatidylinositol 3 kinase).

and (e) concomitantly there was a concurrent increase in LCFA oxidation, possibly as a result of the increased rate of LCFA transport. Importantly, (f) these AICAR-induced effects on protein expression, and fatty acid uptake and oxi- dation were prevented when the AMP-kinase signaling pathway was blocked.

The AICAR induction of LCFA transporter protein expression was very rapid, being already evident after 60 

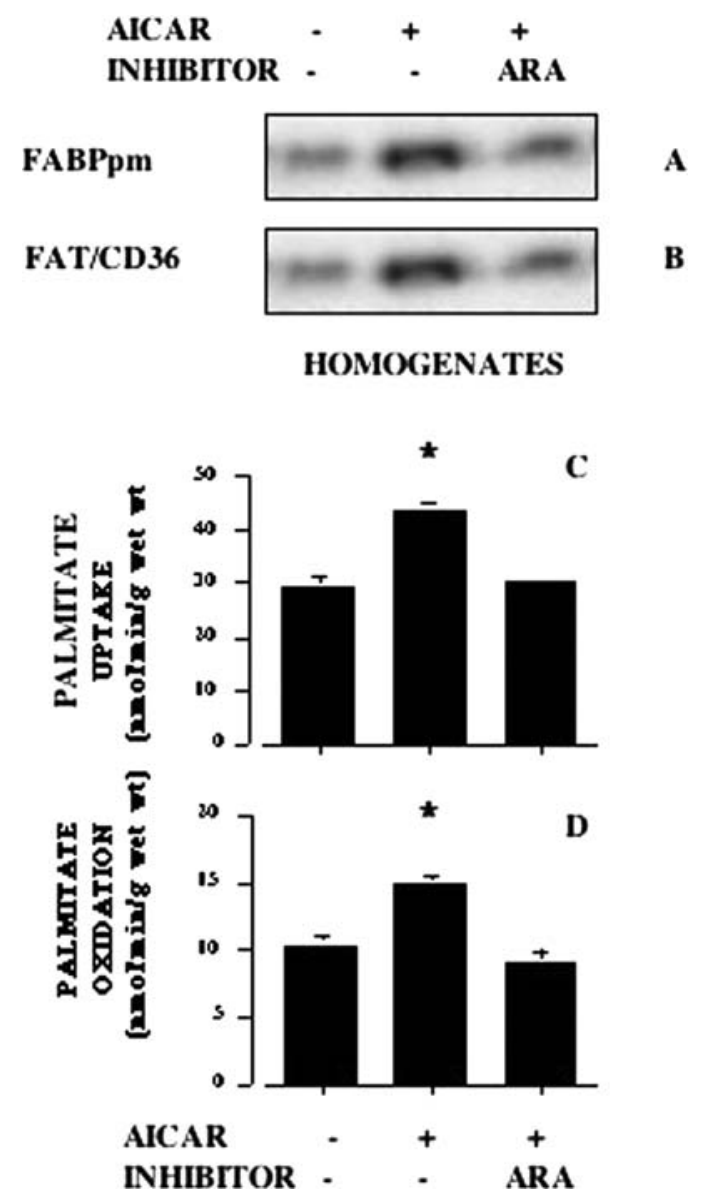

Fig. 6. Effects of AICAR and AICAR+ARA (10 $\mu \mathrm{M}$, adenine 9- $\beta$-Darabino-furanoside) on the expression of FABPpm (A) and FAT/CD36 (B), as well as on the rate of palmitate uptake (C) and oxidation (D) by cardiac myocytes. (mean \pm sem). ${ }^{*} P<0.05$, treatment $v s$ control. For these studies cardiac myocytes, were preincubated for 1 hour at $37^{\circ} \mathrm{C}$ in the absence and/or presence of the inhibitor, followed by incubation with AICAR $(2 \mathrm{mM})$ for 2 hours. Palmitate uptake $(3 \mathrm{~min}$ ) rate was determined at the end of the incubation period while palmitate oxidation was determined during the final $30 \mathrm{~min}$ of incubation.

(FAT/CD36) and $90 \mathrm{~min}$ (FABPpm). Their up-regulation remained stable from 90 to $150 \mathrm{~min}$ for both LCFA transport proteins. This rapid increase in protein expression parallels another study, in which, within 30-200 min., a 1.56.0 fold increase in UCP3 protein was observed in skeletal muscles incubated with AICAR [33]. Furthermore, we [20] have recently shown that insulin rapidly stimulated, via the PI3-kinase/Akt signaling pathway, the overexpression of cardiac myocyte FAT/CD36 protein within $2 \mathrm{~h}$, in a time and dose-dependent manner. But in marked contrast to the present study, insulin did not alter the expression of FABPpm [20]. This indicates that, in the same tissue, there are LCFA transporter-specific responses to different stimuli such as insulin and AICAR, involving different signaling pathways (i.e.
PI3 kinase and AMPK, respectively). We also observed that AICAR induced a strikingly similar effect on the overexpression of both fatty acid transporters in cardiac myocytes and in the perfused heart, suggesting that our observations are relevant in vivo.

Recent studies have provided evidence that AICAR can activate a number of different signaling pathways [52, 53], although little is known as to which one of these is involved in the AICAR-induced protein synthesis in cardiac myocytes. AICAR stimulation of the AMPK cascade promotes activation of pathways to promote ATP generation and inhibits anabolic pathways to limit ATP consumption. Thus, in general, AMPK activation inhibits glycogen, cholesterol, fatty acids and protein synthesis $[54,55]$. Nevertheless, in present study we demonstrated that in cardiac myocytes AMPK activation very rapidly stimulated protein synthesis of the fatty acids transporters, FAT/CD36 and FABPpm. Inhibition with selective blockers of several AICAR-stimulated signalling pathways demonstrated conclusively that FAT/CD36 and FABPpm expression occurs via the AMPK signalling pathway.

As with any inhibitor, ARA may well have nonspecific effects. However, the ARA concentrations used in the present study $(2.5 \mathrm{mM})$ are similar to those used by others $[42,43,56]$. In these recent studies this precursor of ara-ATP, a competitive inhibitor of AMPK, inhibited AICAR-stimulated glucose transport in epitrochlearis muscle (2.5 mM ARA, [43]) and papillary muscle $(2 \mu \mathrm{M}-10 \mathrm{mM}$ ARA, [56]), and prevented AMPK-mediated GLUT4 upregulation in L6 myotubes (1 mM ARA, [42]). ARA appears to inhibit AMPK $\alpha 2$ activity but not AMPK $\alpha 1$ activity [43]. Thus, in the present study and others [42, 43, 56] ARA has proven to be a useful inhibitor with which to determine whether AMPK activation regulates selected metabolic processes.

In the present study, we observed that AICAR not only increases FAT/CD36 and FABPpm expressions, but it also appears to targets both of these transporters to the plasma membrane as shown in the giant vesicles. We are aware that FABPpm is identical to the mitochondrial aspartate aminotransferase $[57,58]$ and we have shown recently that FAT/CD36 is also present in mitochondria [59]. However, our subcellular PM and LDM fractions are not contaminated with mitochondria (data not shown and [20]).

The dual effect of long-term AICAR exposure on fatty acid transporter expression and their increased plasmalemmal content in the heart is similar to that observed for GLUT4 in fast-twitch muscle exposed to AICAR for 5 days; namely, there was an increase in both GLUT4 protein expression and an increase in plasmalemmal GLUT4 [60]. Presumably, the increased plasmalemmal FABPpm and FAT/CD36 reflected the increased protein expression, since the AICAR-induced increases in plasmalemmal protein and their expression were 
very similar (FABPpm protein expression $+27 \%$ and plasma membrane FABPpm +38\%; FAT/CD36 protein expression + $44 \%$ and plasma membrane FAT/CD36 +44\%). Such similar changes were also observed with long-term (5 day) AICAR treatment on GLUT4 expression $(+63 \%)$ and plasmalemmal GLUT4 content $(+68 \%)$ in skeletal muscle [60]. We and Buhl et al. [60] assume that this dual effect on the expression and subcellular localization of glucose and fatty acid transporters is attributable to the well known activation of AMPK by AICAR.

The present studies have also shown the metabolic consequences of AICAR induced changes in the LCFA transporters. This is the first study to show that AICAR-induced an increase in myocardial LCFA transport into giant vesicles, the most suitable system for measuring fatty acid transport [49, 61]. The AICAR-stimulated increase in LCFA transport correlated positively with the increase in plasmalemmal FAT/CD36 and FABPpm. It has been reported in several studies that the changes in subcellular localization of fatty acid transporters show a strong positive relationship with fatty acid transport $[13,17,18,22]$. Our present observations underscore the fact that the subcellular redistribution of LCFA transporters is an important factor that determines cardiac myocytes capacity for fatty acid transport. It is tempting to speculate that this increased rate of fatty acid transport is necessary to ensure sufficient fatty acid provision for mitochondrial oxidation when AMPK is activated. Others have also speculated that it is the increased fatty acid delivery into the heart that provides the additional substrate for oxidation $[3,11,62]$.

In summary, this study has shown that AMPK activation by AICAR very rapidly (1-2h) stimulates the protein expression of both fatty acid transporters, FAT/CD36 and FABPpm, in cardiac myocytes in (a) time- and (b) dose-dependent manner, by (c) transcriptional mechanisms. Importantly, (d) the expression of FAT/CD36 and FABPpm is regulated by the AMPK signaling pathway. In addition, (e) AICAR-induced expression of LCFA transporters was similar in cardiac myocytes and the perfused heart. Finally, (f) there was a positive correlation between the plasmalemmal content of both fatty acids transporters and the rates of LCFA transport into giant vesicles. Thus, prolonged activation of AMPK is a key mechanism regulating the expression fatty acid transporters.

\section{Acknowledgments}

These studies were funded by the Heart and Stroke Foundation of Ontario, the Canadian Institutes of Health Research (CIHR), the Natural Sciences and Engineering Research Council of Canada (NSERC), the Canada Research Chair program, and the Netherlands Heart Foundation (2000.156), J.J.F.P. Luiken is a recipient of a VIDI-Innovation Re- search Grant from the Netherlands Organization for Scientific Research (NWO-ZonMw grant 016.036.305). J.F.C. Glatz is Netherlands Heart Foundation Professor of Cardiac Metabolism. A. Bonen is Canada Research Chair in Metabolism and Health.

\section{References}

1. van der Vusse GJ, Glatz JFC, Stam HCG, Reneman RS: Fatty acid homeostasis in the normoxic and ischemic heart. Physiol Rev 72: 881940, 1992

2. Kudo N, Gillespie JG, Kung L, Witters LA, Schulz R, Clanachan AS, Lopaschuk GD: Characterization of 5'AMP-activated protein kinase activity in the heart and its role in inhibiting acetyl-CoA carboxylase during reperfusion following ischemia. Biochim Biophys Acta 1301: 67-75, 1996

3. Longnus SL, Wambolt RB, Barr RL, Lopaschuk GD, Allard MF: Regulation of myocardial fatty acid oxidation by substrate supply. Am J Physiol Heart Circ Physiol 281: H1561-H1567, 2001

4. Awan MM, Saggerson ED: Malonyl-CoA metabolism in cardiac myocytes and its relevance to the control of fatty acid oxidation. Biochem J 295: 61-66, 1993

5. Kudo N, Barr AJ, Barr RL, Desai S, Lopaschuk GD: High rates of fatty acid oxidation during reperfusion of ischemic hearts are associated with a decrease in malonyl-CoA levels due to an increase in 5'-AMP-activated protein kinase inhibition of acetyl-CoA carboxylase. J Biol Chem 270: 17513-17520, 1995

6. Lopaschuk GD, Witters LA, Itoi T, Barr R, Barr A: Acetyl-CoA carboxylase involvement in the rapid maturation of fatty acid oxidation in the newborn rabbit heart. J Biol Chem 269: 25871-25878, 1994

7. Ruderman NB, Dean D: Malonyl CoA, long chain fatty acyl CoA and insulin resistance in skeletal muscle. J Basic Clin Physiol Pharmacol 9: 295-308, 1998

8. Ruderman NB, Saha AK, Vavvas D, Kurowski T, Laybutt DR, SchmitzPeiffer C, Biden T, Kraegen EW: Malonyl CoA as a metabolic switch and a regulator of insulin sensitivity. Adv Exp Med Biol 441: 263-270, 1998

9. Ruderman NB, Saha AK, Vavvas D, Witters LA: Malonyl CoA, fuel sensing and insulin resistance. Am J Physiol Endocrinol Metab 276: E1-E18, 1999

10. Atkinson LL, Kozak R, Kelly SE, Onay-Besikci A, Russell JC, Lopaschuk GD: Potential mechanisms and consequences of cardiac triacylglycerol accumulation in insulin-resistant rats. Am J Physiol Endocrinol Metab 284: E923-E920, 2003

11. Shearer J, Fueger PT, Rottman JN, Bracy DP, Martin PH, Wasserman DH: AMPK stimulation increases LCFA but not glucose clearance in cardiac muscle in vivo. Am J Physiol Endocrinol Metab 287: E871-877, 2004

12. Coort SLM, Hasselbaink DM, Koonen DYP, Willems J, Coumans WA, Chabowski A, van der Vusse GJ, Bonen A, Glatz JFC, Luiken JJFP: Enhanced sarcolemmal FAT/CD36 content and triacylglycerol storage in cardiac myocytes from obese Zucker rats. Diabetes 53: 1655-1663, 2004

13. Bonen A, Luiken JJFP, Arumugam Y, Glatz JFC, Tandon NN: Acute regulation of fatty acid uptake involves the cellular redistribution of fatty acid translocase. J Biol Chem 275: 14501-14508, 2000

14. Clarke DC, Miskovic D, Han X-X, Calles-Escandon J, Glatz JFC, Luiken JJFP, Heikkila JJ, Bonen A: Overexpression of membrane associated fatty acid binding protein (FABPpm) in vivo increases fatty acid 
sarcolemmal transport and metabolism. Physiol Genomics 17: 31-37, 2004

15. Coburn CT, Knapp Jr FF, Febbraio M, Beets AL, Silverstein RL, Abumrad NA: Defective uptake and utilization of long chain fatty acids in muscle and adipose tissue of CD36 knockout mice. J Biol Chem 275: 32523-32529, 2000

16. Stahl A, Evans JG, Pattel S, Hirsch D, Lodish HF: Insulin causes fatty acid transport protein translocation and enhanced fatty acid uptake in adipocytes. Dev Cell 2: 477-488, 2002

17. Luiken JJFP, Koonen DPY, Willems J, Zorzano A, Fischer Y, van der Vusse GJ, Bonen A, Glatz JFC: Insulin stimulates long-chain fatty acid uilization by rat cardiac myocytes through cellular redistribution of FAT/CD36. Diabetes 51: 3113-3119, 2002

18. Luiken JJFP, Coort SML, Willems J, Coumans WA, Bonen A, van der Vusse GJ, Glatz JFC: Contraction-induced fatty acid translocase/CD36 translocation in rat cardiac myocytes is mediated through AMP-activated protein kinase signaling. Diabetes 52: 1627-1634, 2003

19. Bonen A, Luiken JJFP, Lui S, Dyck DJ, Kiens B, Kristiansen S, Turcotte L, van der Vusse GJ, Glatz JFC: Palmitate transport and fatty acid transporters in red and white muscles. Am J Physiol Endocrinol Metab 275: E471-E478, 1998

20. Chabowski A, Coort SL, Calles-Escandon J, Tandon NN, Glatz JF, Luiken JJ, Bonen A: Insulin stimulates fatty acid transport by regulating expression of FAT/CD36 but not FABPpm. Am J Physiol Endocrinol Metab 287: E781-E789, 2004

21. Hirsch D, Stahl A, Lodish HF: A family of fatty acid transporters conserved from mycobacterium to man. Proc Natl Acad Sci USA 95: 86258629,1998

22. Luiken JJFP, Dyck DJ, Han X-X, Tandon NN, Arumugam Y, Glatz JFC, Bonen A: Insulin induces the translocation of the fatty acid transporter FAT/CD36 to the plasma membrane. Am J Physiol Endocrinol Metab 282: E491-E495, 2002

23. Gimeno RE, Ortegon AM, Patel S, Punreddy S, Ge P, Sun Y, Lodish HF, Stahl A: Characterization of a heart-specific fatty acid transport protein. J Biol Chem 278: 16039-16044, 2003

24. Glatz JFC, Luiken J, Bonen A: Exercise and insulin increase muscle fatty acid uptake by recruiting puttaive fatty acid transporters to the sarcolemma. Curr Opin Clin Nutr Metab Care 5: 365-370, 2002

25. Luiken JJ, Coort SL, Willems J, Coumans WA, Bonen A, Glatz JF: Dipyridamole alters cardiac substrate preference by inducing translocation of FAT/CD36, but not that of GLUT4. Mol Pharmacol 65: 639-645, 2004

26. Chabowski A, Coort SLM, Calles-Escandon J, Tandon NN, Glatz JFC, Luiken JJFP, Bonen A: The subcellular compartmentation of fatty acid transporters is regulated differently by insulin and by AICAR. FEBS Lett 579: 2428-2432, 2005

27. Ibrahimi A, Bonen A, Blinn WD, Hajri T, Li X, Zhong K, Cameron R, Abumrad NA: Muscle-specific overexpression of FAT/CD36 enhances fatty acid oxidation by contracting muscles, reduces plasma triglycerides and fatty acids, and increases plasma glucose and insulin. J Biol Chem 274: 26761-26766, 1999

28. Koonen DPY, Benton CR, Arumugam Y, Tandon NN, Calles-Escandon J, Glatz JFC, Luiken JJFP, Bonen A: Different mechanism can alter fatty acid transport when muscle contractile activity is chronically altered. Am J Physiol Endocrinol Metab 286: 1042-1049, 2004

29. Batt J, Bain J, Goncalves J, Michalski B, Plant P, Fahnestock M, Woodgett J: Differential gene expression profiling of short and long term denervated muscle. Faseb J 20: 115-117, 2006

30. Kahn BB, Alquier T, Carling D, Hardie G: AMP-activated protein kinase: Ancient energy gauge provides clues to modern understanding of metabolism. Cell Metabolism 1: 15-25, 2005
31. Smith AC, Bruce CR, Dyck DJ: AMP kinase activation with AICAR simultaneously increases fatty acid and glucose oxidation in resting rat soleus muscle. J Physiol 565: 537-546, 2005

32. Smith AC, Bruce CR, Dyck DJ: AMP kinase activation with AICAR further increases fatty acid oxidation and blunts triacylglycerol hydrolysis in contracting rat soleus muscle. J Physiol 565: 547-553, 2005

33. Zhou M, Lin B-Z, Coughlin S, Vallega G, Pilch PF: UCP-3 expression in skeletal muscle: effects of exercise, hypoxia and AMP-activated protein kinase. Am J Physiol Endocrinol Metab 279: E622-E629, 2000

34. Jessen N, Pold R, Buhl ES, Jensen LS, Schmitz O, Lund S: Effects of AICAR and exercise on insulin-stimulated glucose uptake, signaling, and GLUT-4 content in rat muscles. J Appl Physiol 94: 1373-1379, 2003

35. Putman CT, Kiricsi M, Pearcey J, MacLean IM, Bamford JA, Murdoch GK, Dixon WT, Pette D: AMPK activation increases uncoupling protein-3 expression and mitochondrial enzyme activities in rat muscle without fibre type transitions. J Physiol 551: 169-178, 2003

36. Sakoda H, Ogihara T, Anai M, Fujishiro M, Ono H, Onishi Y, Katagiri H, Abe M, Fukushima Y, Shojima N, Inukai K, Kikuchi M, Oka Y, Asano T: Activation of AMPK is essential for AICAR-induced glucose uptake by skeletal muscle but not adipocytes. Am J Physiol Endocrinol Metab 282: E1239-E1244, 2002

37. Luiken JJFP, Coort SLM, Koonen DPY, van der Horst DJ, Bonen A, Zorzano A, Glatz JFC: Regulation of cardiac long-chain fatty acid and glucose uptake by translocation of substrate transporters. Pflugers Archiv 448: 1-45, 2004

38. Koonen DP, Glatz JF, Bonen A, Luiken JJ: Long-chain fatty acid uptake and FAT/CD36 translocation in heart and skeletal muscle. Biochim Biophys Acta 1736: 163-180, 2005

39. Matsuno K, Diaz-Ricard M, Montgomery RR, Aster T, Jamieson GA, Tandon NN: Inhibition of platelet adhesion to collagen by monoclonal anti CD36 antibodies. Br J Haematol 92: 960-967, 1996

40. Calles-Escandon J, Sweet L, Ljungqvist O, Hirshman MF: The membrane associated $40 \mathrm{kDa}$ fatty acid binding protein is present in human skeletal muscle. Life Sci 58: 19-28, 1996

41. Fischer Y, Rose H, Kammermeier H: Highly insulin responsive isolated rat heart muscle cells yield by a modified isolation method. Life Sci 49 : 1679-1688, 1991

42. Ojuka EO, Jones TE, Nolte LA, Chen M, Wamhoff BR, Sturek M, Holloszy JO: Regulation of GLUT4 biogenesis in muscle: evidence for involvement of AMPK and $\mathrm{Ca}(2+)$. Am J Physiol Endocrinol Metab 282: E1008-E1013, 2002

43. Musi N, Hayashi T, Fujii N, Hirshman MF, Witters LA, Goodyear LJ: AMP-activated protein kinase activity and glucose uptake in rat skeletal muscle. Am J Physiol Endocrinol Metab 280: E677-E684, 2001

44. Sajan MP, Standaert ML, Bandypadhyay G, Qoun MJ, Burke TR, Farese RV: Protein kinase C-zeta and phosphoinositide-dependent protein kinase-1 are required for insulin-induced activation of ERK in rat adipocytes. J Biol Chem 274: 30495-30500, 1999

45. Favata MF, Horiuchi KY, Manos EJ, Daulerio AJ, Stradley DA, Feeser WS, Van Dyk DE, Pitts WJ, Earl RA, Hobbs F, Copeland RA, Magolda RL, Scherle PA, Trzaskos JM: Identification of a novel inhibitor of mitogen-activated protein kinase kinase. J Biol Chem 273: 18623-18632, 1998

46. Vlahos CJ, Matter WF, Hui KY, Brown RF: A specific inhibitor of phosphatidylinositol 3-kinase, 2-(4-morpholinyl)-8-phenyl-4H-1benzopyran-4-one (LY294002). J Biol Chem 269: 5241-5248, 1994

47. Luiken JJFP, van Nieuwenhoven FA, America G, van der Vusse GJ, Glatz JFC: Uptake and metabolism of palmitate by isolated cardiac myocytes from adult rats: Involvement of sarcolemmal proteins. J Lipid Res 38: 725-758, 1997 
48. Coort SL, Luiken JJ, Van Der Vusse GJ, Bonen A, Glatz JF: Increased FAT (fatty acid translocase)/CD36-mediated long-chain fatty acid uptake in cardiac myocytes from obese Zucker rats. Biochem Soc Trans 32: 83-85, 2004

49. Luiken JJFP, Turcotte LP, Bonen A: Protein-mediated palmitate uptake and expression of fatty acid transport proteins in heart giant vesicles. J Lipid Res 40: 1007-1016, 1999

50. Soltys CL, Buchholz L, Gandhi M, Clanachan AS, Walsh K, Dyck JR: Phosphorylation of cardiac protein kinase $\mathrm{B}$ is regulated by palmitate. Am J Physiol Heart Circ Physiol 2002: H1056-H1064, 2002

51. Bolster DR, Crozier SJ, Kimball SR, Jefferson LS: AMP-activated protein kinase suppresses protein synthesis in rat skeletal muscle through down-regulated mammalian target of rapamycin (mTOR) signaling. $\mathbf{J}$ Biol Chem 277: 23977-23980, 2002

52. Winder WW, Hardie DG: AMP-activated protein kinase, a metabolic master switch: Possible roles in type 2 diabetes. Am J Physiol 277: E1-10, 1999

53. Hue L, Beauloye C, Marsin AS, Bertrand L, Horman S, Rider MH: Insulin and ischemia stimulate glycolysis by acting on the same targets through different and opposing signaling pathways. J Mol Cell Cardiol 34: 1091-1097, 2002

54. Winder WW, Hardie DG: Inactivation of acetyl-CoA carboxylase and activation of AMP-activated protein kinase in muscle during exercise. Am J Physiol 270: E299-E304, 1996

55. Vavvas D, Apazidis A, Saha AK, Gamble J, Patel A, Kemp BE, Witters LA, Ruderman NB: Contraction-induced changes in acetyl-CoA carboxylase and $5^{\prime}$-AMP-activated kinase in skeletal muscle. J Biol Chem 272: 13255-13261, 1997
56. Russell RR, 3rd, Bergeron R, Shulman GI, Young LH: Translocation of myocardial GLUT-4 and increased glucose uptake through activation of AMPK by AICAR. Am J Physiol 277: H643-H649, 1999

57. Stump DD, Zhou S-L, Berk PD: Comparison of plasma membrane FABP and mitochondrial isoform of aspartate aminotransferase from rat liver. Am J Physiol Gastrointest Liver Physiol 265: G894-G902, 1993

58. Bradbury MW, Berk PD: Mitochondrial aspartate aminotransferase: Direction of a single protein with two distinct functions to two subcellular sites does not require alternative splicing of the mRNA. Biochem J 345 : 423-427, 2000

59. Campbell SE, Tandon NN, Woldegiorgis G, Luiken JJFP, Glatz JFC, Bonen A: A novel function for FAT/CD36: involvement in long chain fatty acid transfer into the mitochondria. J Biol Chem 279: 3632536341, 2004

60. Buhl ES, Jessen N, Schmitz O, Pedersen SB, Pedersen O, Holman GD, Lund S: Chronic treatment with 5-aminoimidazole-4-carboxamide$1-\beta$-D-ribofuranoside increases insulin-stimulated glucose uptake and GLUT4 translocation in rat skeletal muscles in a fiber type-specific manner. Diabetes 50: 12-17, 2001

61. Koonen DPY, Coumans WA, Arumugam Y, Bonen A, Glatz JFC, Luiken JJFP: Giant membrane vesicles as a model to study cellular substrate uptake dissected from metabolism. Mol Cell Biochem 239: 121-130, 2002

62. Atkinson LL, Fischer MA, Lopaschuk GD: Leptin activates cardiac fatty acid oxidation independent of changes in the AMP-activated protein kinase-acetyl-CoA carboxylase-malonyl-CoA axis. J Biol Chem 277: 29424-29430, 2002 